\title{
PERANCANGAN DAN IMPLEMENTASI SISTEM MONITORING PRODUKSI BIOGAS PADA BIODIGESTER
}

\author{
Rocky Alfanz $^{1^{*}}$, Agus Nurhadi $^{2}$, Joddy Arya Laksmono $^{3}$ \\ 1,2Jurusan Teknik Elektro, Fakultas Teknik, Universitas Sultan Ageng Tirtayasa \\ ${ }^{3}$ Pusat Penelitian Kimia, Lembaga Ilmu Pengetahuan Indonesia \\ *Corresponding author, e-mail : rocky.alfanz@ ft-untirta.ac.id
}

\begin{abstract}
Abstrak - Biogas merupakan salah satu gas alam yang dapat terbakar, kandungan yang paling banyak diobservasi dalam penelitian ini adalah gas metana $\left(\mathrm{CH}_{4}\right)$, hidrogen $\left(\mathrm{H}_{2}\right)$ dan karbon dioksida $\left(\mathrm{CO}_{2}\right)$, hal inilah yang menjadikan biogas dapat dikembangkan dan digunakan sebagai energi alternatif. Namun pada umumnya plant biodigester yang digunakan untuk memproduksi biogas masih sangat sederhana, sehingga dibutuhkan perancangan sistem yang dapat membantu proses monitoring produksi biogas. Pada penelitian ini dirancang sebuah sistem yang dapat melakukan proses akuisisi data menggunakan sensor gas metana MQ4, sensor gas hidrogen MQ8 dan sensor gas Karbon dioksida MG811 serta parameter yang berpengaruh pada proses produksi biogas seperti suhu, kelembaban dan tekanan. Berdasarkan pengukuran terhadap gas metana, didapatkan titik tertinggi produksi gas terjadi pada pukul 10:00 dengan kondisi pengukuran suhu: $34^{\circ} \mathrm{C}$, kelembaban: $67 \% \mathrm{RH}$, dan tekanan: 100,6 kPa menghasilkan gas metana sebesar 95.672 ppm. Untuk pengukuran gas hidrogen didapatkan titik tertinggi produksi gas terjadi pada pukul 14:00 dengan kondisi pengukuran suhu $34^{\circ} \mathrm{C}$, kelembaban $74 \% \mathrm{RH}$, dan tekanan $100,4 \mathrm{kPa}$ menghasilkan gas hidrogen sebesar 4,378 ppm. Pada pengukuran gas karbondioksida titik tertinggi produksi gas terjadi pada pukul 11:00 dengan kondisi pengukuran suhu $33^{\circ} \mathrm{C}$, kelembaban $68 \% \mathrm{RH}$, dan tekanan $100,5 \mathrm{kPa}$ menghasilkan gas karbondioksida sebesar 16,89 ppm.
\end{abstract}

Kata Kunci : Biodigester, Sistem Monitoring, Biogas, DAQ

\begin{abstract}
Biogas is one of the flammable natural gas. The most observed content of biogas in this study is methane $\left(\mathrm{CH}_{4}\right)$, hydrogen $\left(\mathrm{H}_{2}\right)$ and carbon dioxide $\left(\mathrm{CO}_{2}\right)$. Therefore, biogas can be developed and used as an alternative energy. Nowadays, the used of plant biodigester, as the biogas producer, is still in very simple design. So, the system design should be developed to assist the monitoring process of biogas production. In this study, a system is design which can do the data acquisition using MQ4 sensor of methane, MQ8 sensor of hydrogen and MG811 sensor of carbon dioxide also the parameter which influencing to the process of biogas production such as temperature, humidity and pressure. Based on the measurement of methane, it is spotted that the highest point of methane production occured at 10:00 a.m. The details were the temperature $34{ }^{\circ} \mathrm{C}$, humidity $67 \% \mathrm{RH}$, and pressure $100,6 \mathrm{kPa}$ which can produce $95.672 \mathrm{ppm}$ of methane. In the measurement of hydrogen, it is figured out that the highet point of hydrogen production occured at 02:00 p.m. The details were the temperature $34{ }^{\circ} \mathrm{C}$, humidity $74 \% \mathrm{RH}$, and a pressure of $100,4 \mathrm{kPa}$ to produce $4,738 \mathrm{ppm}$ of hydrogen. Then, the highest point of the measurement of carbon dioxide production occurred at 11:00 a.m. The details were temperature $33{ }^{\circ} \mathrm{C}$, humidity $68 \% \mathrm{RH}$, and a pressure of $100,5 \mathrm{kPa}$ to $16,89 \mathrm{ppm}$ of carbon dioxide.
\end{abstract}

Keywords : Biodigester, Monitoring System, Biogas, DAQ

Copyright $\odot 2016$ JNTE. All rights reserved

\section{PENDAHULUAN}

\subsection{Latar Belakang}

Peternakan sapi merupakan salah satu tempat yang banyak digunakan untuk melakukan penelitian tentang biogas, karena kotoran sapi merupakan salahsatu sumber utama untuk membentuk biogas. Seperti peternakan sapi yang terletak di kawasan pusat pengembangan ilmu pengetahuan dan teknologi (PUSPIPTEK) serpong yang memiliki instalasi digester biogas berkapasitas $50 \mathrm{~m}^{3}$ sebanyak 2 buah dan gas holder berukuran $10 \mathrm{~m}^{3}$ sebanyak 3 buah, dengan produksi biogas $\pm 30 \mathrm{~m}^{3}$ perhari.

Biogas merupakan suatu jenis gas yang dapat dibakar, yang diproduksi melalui proses fermentasi aerobik dan anaerobik dari bahan organik seperti kotoran ternak dan manusia, 
biomassa limbah pertanian atau campuran keduanya, didalam suatu ruang pencerna (digester), kandungan biogas yang banyak diteliti yaitu, gas metana, gas karbondioksida dan gas hidrogen [1].

Gas metana $\left(\mathrm{CH}_{4}\right)$ yang merupakan komponen utama biogas dapat menjadi bahan bakar yang berguna karena mempunyai nilai kalor yang cukup tinggi, yaitu sekitar 4800$6700 \mathrm{kkal} / \mathrm{m}^{3}$, sedangkan gas metana murni mengandung energi $8900 \mathrm{kkal} / \mathrm{m}^{3}$ [2]. Karena nilai kalor yang cukup tinggi itulah biogas dapat dipergunakan untuk keperluan penerangan, memasak, menggerakkan mesin dan sebagainya. Sistem produksi biogas juga mempunyai beberapa keuntungan yaitu mengurangi pengaruh gas rumah kaca, mengurangi polusi bau yang tidak sedap, sebagai pupuk, dan produksi daya dan panas [1].

Selain metana, hidrogen $\left(\mathrm{H}_{2}\right)$ juga dapat dimanfaatkan sebagai bahan bakar alternatif dimana $95 \%$ gas hidrogen yang digunakan pada saat ini berasal dari pemrosesan gas alam (Natural Gases) yang salah satunya didapat pada biogas hasil fermentasi bahan alam dalam biodigester [3].

Gas karbondioksida $\left(\mathrm{CO}_{2}\right)$ juga merupakan gas yang banyak diproduksi pada biogas, hal ini memungkinkan untuk mengetahui perkiraan pertumbuhan gas efek rumah kaca pada wilayah tertentu dengan mengukur kadar gas karbondioksida pada wilayah tersebut. Sehingga dapat dilakukan beberapa hal yang dapat mengurangi pertumbuhan gas efek rumah kaca [4].

Biodigester (Reaktor Biogas) berfungsi mengubah kotoran binatang, kotoran manusia dan materi organik lainnya, menjadi biogas. Teknologi reaktor yang sudah banyak digunakan di Indonesia adalah teknologi BIRU. Teknologi BIRU merupakan teknologi reaktor kubah beton (fixed-dome) yang diadaptasi dari sistem yang telah digunakan di negara lain seperti Banglades, Kamboja, Laos, Pakistan, Nepal dan Vietnam. Reaktor kubah beton ini terbuat dari batu-bata dan beton yang tertutup di bawah tanah. Sistem ini terbukti aman bagi lingkungan dan berfungsi sebgai sumber energi yang bersih. Di Nepal, teknologi ini digunakan oleh lebih dari 200 ribu rumah tangga selama lebih dari 15 tahun, dengan 95\% reaktor masih berfungsi [5].

Pada umumnya plant biodigester yang ada saat ini masih belum dilengkapi dengan sistem monitoring volume gas yang dihasilkan dalam biodigester, dan dibutuhkan sebuah sistem yang dapat diimplementasikan pada plant biodigester ini. Pada penelitian ini merancang sebuah sistem monitoring yang dapat memantau konsentrasi gas metana, karbon dioksida dan hidrogen serta mengetahui beberapa faktor yang mempengaruhi produksi biogas seperti suhu, kelembaban, dan tekanan dalam biodigester.

\section{TINJAUAN PUSTAKA}

\subsection{Data Acquisition (DAQ)}

Data Acquisition (DAQ) adalah proses mengukur fenomena listrik atau fisik seperti tegangan, arus, suhu, tekanan, atau suara dengan komputer. Sebuah Sistem DAQ terdiri dari sensor, perangkat keras pengukuran DAQ, dan komputer dengan software yang telah diprogram. Dibandingkan dengan sistem pengukuran tradisional, sistem DAQ berbasis PC mengeksploitasi kekuatan pemrosesan, produktifitas, tampilan, dan kemampuan konektifitas komputer standar industri menyediakan solusi pengukuran yang lebih kuat, fleksibel, dan hemat biaya. Sistem akuisisi data juga dapat didefinisikan sebagai suatu sistem yang berfungsi untuk mengambil, mengumpulkan dan menyiapkan data, hingga memprosesnya untuk menghasilkan data yang dikehendaki. Jenis serta metode yang di pilih pada umumnya bertujuan untuk menyederhanakan setiap langkah yang dilaksanakan pada keseluruhan proses. Suatu sistem akuisisi data pada umumnya dibentuk sedemikian rupa sehingga sistem tersebut berfungsi untuk mengambil, mengumpulkan dan menyimpan data dalam bentuk yang siap untuk diproses lebih lanjut [6]. Gambar 1 adalah proses akuisisi data.

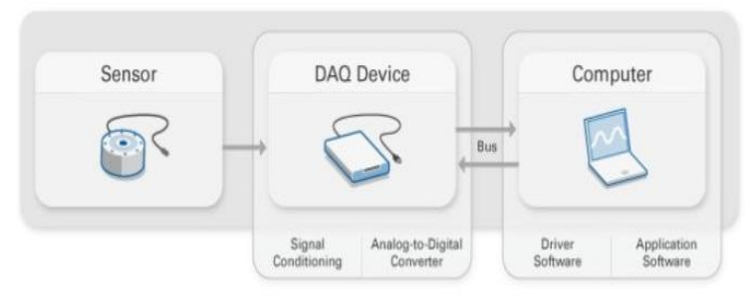

Gambar 1. Diagram blok bagian sistem akuisisi data [6] 


\subsection{Sistem Monitoring}

Sistem adalah suatu kesatuan yang terdiri dari dua atau lebih komponen subsistem yang saling berinteraksi untuk mencapai tujuan tertentu. Sedangkan monitoring adalah proses rutin pengumpulan data dan pengukuran terhadap objek tertentu. Maka, sistem monitoring merupakan suatu perangkat yang saling terkait dan mempunyai fungsi sebagai alat pemantau [7].

\subsection{Real-time Sistem}

Real time system disebut juga dengan sistem waktu nyata. Sistem yang harus menghasilkan respon yang tepat dalam batas waktu yang telah ditentukan. Jika respon komputer melewati batas waktu tersebut, maka terjadi degradasi performansi atau kegagalan sistem. Sebuah real time system adalah sistem yang kebenarannya secara logis didasarkan pada kebenaran hasil-hasil keluaran sistem dan ketepatan waktu hasil-hasil tersebut dikeluarkan. Aplikasi penggunaan sistem seperti ini adalah untuk memantau dan mengontrol peralatan seperti motor, assembly line, teleskop, atau instrumen lainnya. Peralatan telekomunikasi dan jaringan komputer biasanya juga membutuhkan pengendalian secara real time. Berdasarkan batasan waktu yang dimilikinya, real-time system ini dibagi atas beberapa jenis. Diantaranya yaitu, hard real time system, soft real- time system [8].

\subsection{Biogas}

Biogas merupakan suatu jenis gas yang bisa dibakar, yang diproduksi melalui proses fermentasi anaerobik bahan organik seperti kotoran ternak dan manusia, biomassa limbah pertanian atau campuran keduanya, didalam suatu ruang pencerna (digester). Komposisi biogas yang dihasilkan dari fermentasi tersebut terbesar adalah gas Methan $\left(\mathrm{CH}_{4}\right)$ serta gas karbondioksida $\left(\mathrm{CO}_{2}\right)$.

Selain kedua gas tersebut dalam digester pula menghasilkan gas-gas yang relative kecil seperti gas Oksigen $\left(\mathrm{O}_{2}\right)$, Nitrogen $\left(\mathrm{N}_{2}\right)$, Amonia $\left(\mathrm{NH}_{3}\right)$, Hidrogen $\left(\mathrm{H}_{2}\right)$, serta Hidrogen Sulfida $\left(\mathrm{H}_{2} \mathrm{~S}\right)$ (Al Seadi dkk, 2008) [1][2].

\section{METODOLOGI PENELITIAN}

Metodologi pada penelitian ini dilakukan melalui 4 tahap, yaitu tahap perancangan sistem monitoring, tahap pengujian sistem monitoring, tahap implementasi sistem monitoring dan tahap pengujian pengaruh suhu, kelembaban, dan tekanan. Secara lengkap dapat dilihat pada Gambar 2.

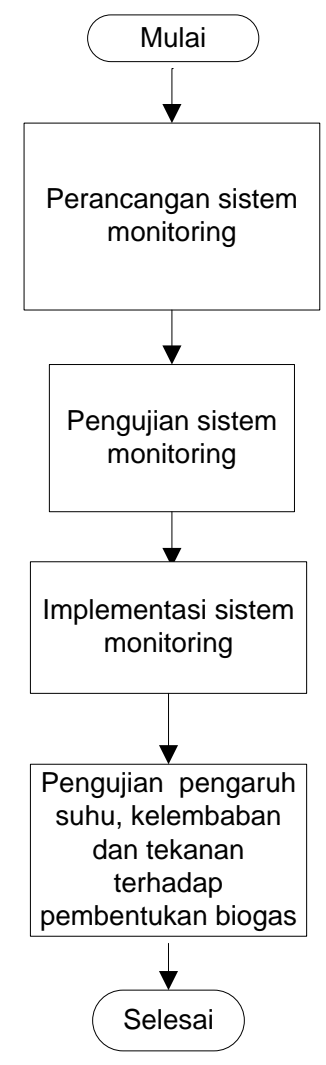

Gambar 2. Flowchart penelitian

\section{HASIL DAN PEMBAHASAN}

Dengan menggunakan rangkaian hasil rancangan sistem senor seperti pada gambar 3 , dilakukan pengujian. Pengujian sensor terhadap gas MQ4, gas MQ 8 dan gas MG811.

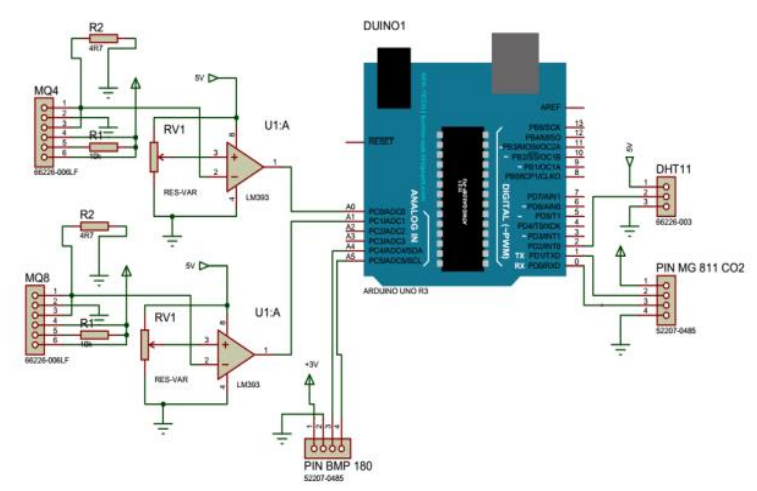

Gambar 3. Skema rangkaian sistem sensor 


\subsection{Pengujian sensor gas MQ4}

Pengujian ini bertujuan untuk mengetahui apakah sistem ini dapat berjalan dengan baik pada saat diimplementasikan untuk melakukan monitoring terhadap gas metana dalam biodigester atau tidak. Pengujian dilakukan dengan memonitoring proses produksi biogas sejak dibuatnya campuran feses sapi dengan air dimasukkan dalam biodigester. Proses monitoring dilakukan dengan dua cara, yaitu dengan memanfaatkan program PLX DAQ yaitu sebuah plugin untuk merekam data serial pada program excel dan melalui proses datalogging sistem menggunakan perangkat datalogger yang kemudian data disimpan pada SDCard selama kurang lebih 7 jam, mulai pukul 8:00 sampai pukul 15:00. Pada proses pengujian ini data di cuplik setiap 1 detik sekali, sementara data yang di analisa adalah data setiap 30 menit sekali.

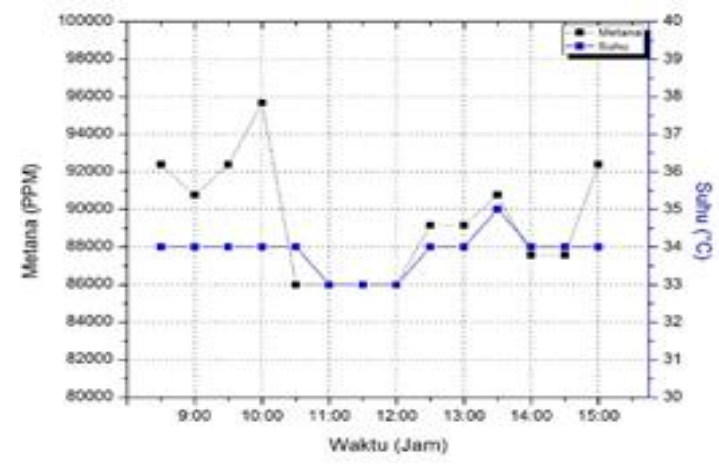

Gambar 4. Pengaruh suhu terhadap produksi gas metana

Berdasarkan pengujian yang ditampilkan pada Gambar 4 diperoleh data pengujian pengaruh parameter suhu terhadap pembentukan gas metana dalam biodigester. Pembentukan gas metana paling tinggi terjadi pada saat suhu $34^{\circ} \mathrm{C}$ dengan keluaran sensor mencapai $95.672 \mathrm{ppm}$ pada pukul 10:00. Namun pada pukul 10:30 konsentrasi gas metana yang terbaca oleh sensor turun menjadi $86.000 \mathrm{ppm}$, lalu pada saat pukul 12:30 konsentrasi gas kembali naik menjadi 89.155 ppm pada saat suhu naik dari $33^{\circ} \mathrm{C}$ menjadi $34^{\circ} \mathrm{C}$. Pada saat suhu kembali naik menjadi $35^{\circ} \mathrm{C}$, produksi gas metana naik kembali menjadi $90.760 \mathrm{ppm}$, kondisi ini terjadi pada pukul 13:30. Ketika suhu mengalami penurunan dari $35^{\circ} \mathrm{C}$ menjadi $34^{\circ} \mathrm{C}$ produksi menurun hingga konsentrasi 87.567 ppm kondisi ini terjadi pada pukul 14:00.

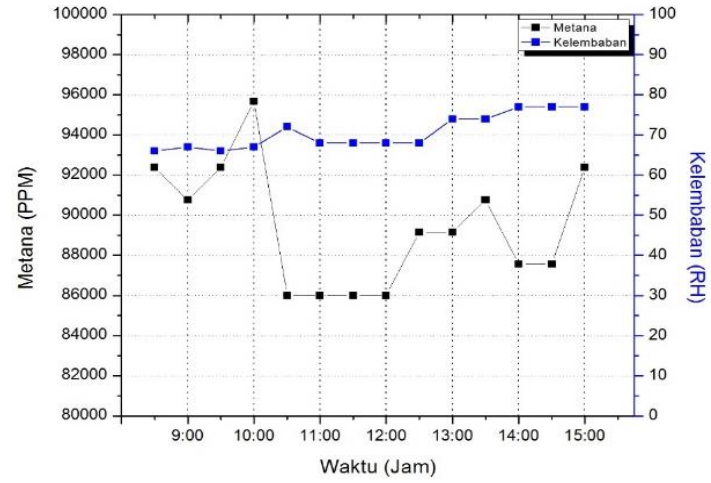

Gambar 5. Pengaruh kelembaban terhadap produksi gas metana

Pada Gambar 5 pengujian pengaruh kelembaban terhadap produksi gas metana pada menunjukkan bahwa kelembaban juga berpengaruh terhadap produksi gas metana dalam biodigester. Pada saat kelembaban meningkat dari $66 \%$ ke $67 \%$, produksi gas metana mengalami penurunan dari $92.381 \mathrm{ppm}$ menjadi 90.760 ppm dan ketika kelembaban kembali menurun menjadi $66 \%$ produksi gas metana naik menjadi 92.381 ppm. Produksi gas metana tertinggi terjadi pada kondisi kelembaban 67\% pada pukul 10:00 menghasilkan gas metana sebesar 95.672 ppm, sementara pada saat kelembaban naik menjadi $72 \%$ produksi gas metana mengalami penurunan yang sangat darastis hingga $85.995 \mathrm{ppm}$ pada pukul 10:30. Hal ini menunjukkan bahwa perubahan kelembaban berbanding terbalik terhadap produksi gas metana.

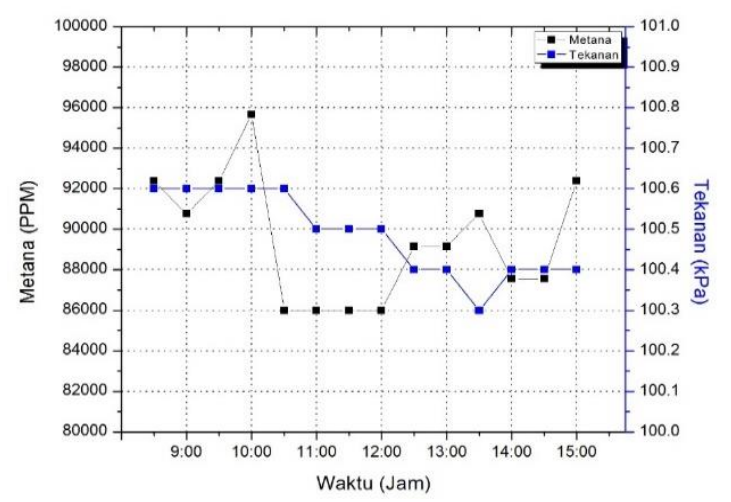

Gambar 6. Pengaruh tekanan terhadap produksi gas metana

Tekanan juga menjadi salah satu faktor yang dapat mempengaruhi produksi biogas, 
seperti terlihat pada Gambar 6. pengaruh tekanan terhadap produksi gas metana. Kondisi puncak produksi gas metana terjadi pada saat tekanan menunjukkan 100,6 kPa. Kemudian pada pukul $13: 30$ terjadi penurunan tekanan dari $100,4 \mathrm{kPa}$ menjadi $100,3 \mathrm{kPa}$ hal ini mempengaruhi produksi gas metana yang naik dari $89.155 \mathrm{ppm}$ menjadi 90.760 ppm. Hal ini menunjukkan bahwa pengaruh tekanan hampir sama seperti pengaruh kelembaban terhadap produksi gas metana, yaitu berbanding terbalik terhadap produksinya.

\subsection{Pengujian sensor gas MQ8}

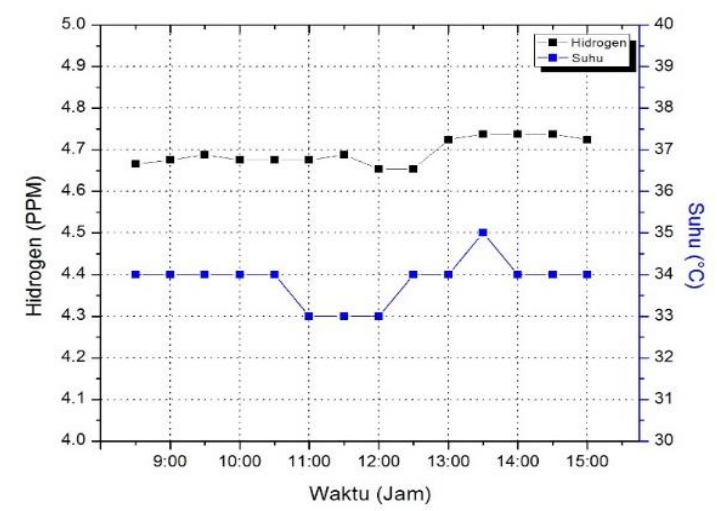

Gambar 7. Pengaruh suhu terhadap produksi gas hydrogen

Pada pengujian ini terlihat bahwa pada rentang pukul 8:30-10:30 tidak terjadi perubahan produksi gas hydrogen yang signifikan yaitu berada pada rentang 4,56 - 4,58 ppm, hal ini karena suhu dalam kondisi yang stabil yaitu menunjukkan pada suhu $34^{\circ} \mathrm{C}$, kemudian pada pukul 11:00 terjadi penurunan suhu menjadi $33^{\circ} \mathrm{C}$ namun produksi tetap dalam kondisi yang sama seperti sebelumnya. Titik tertinggi produksi gas hidrogen terjadi pada pukul 13:30$14: 30$ pada saat suhu mencapai $35^{\circ} \mathrm{C}$ menghasilkan produksi gas hidrogen sebesar 4,738 ppm, namun pada pukul 14:00 suhu menurun menjadi $34^{\circ} \mathrm{C}$ tetapi produksi tidak berubah dan kembali stabil sampai pukul 15:00.

Kelembaban cukup berpengaruh pada proses produksi gas hidrogen kali ini, walaupun produksi hidrogen relatif stabil pada pukul 8:30 12:30 dengan kondisi rentang produksi 4,654,68 ppm, namun terdapat beberapa waktu pengukuran yang menunjukkan adanya pengaruh kelembaban terhadap produksi gas hidrogen. Seperti pada pukul 13:00, terjadi peningkatan produksi gas hidrogen yang semula 4,65 ppm menjadi 4,72 ppm dengan kondisi kelembaban naik dari $68 \%$ menjadi $74 \%$.

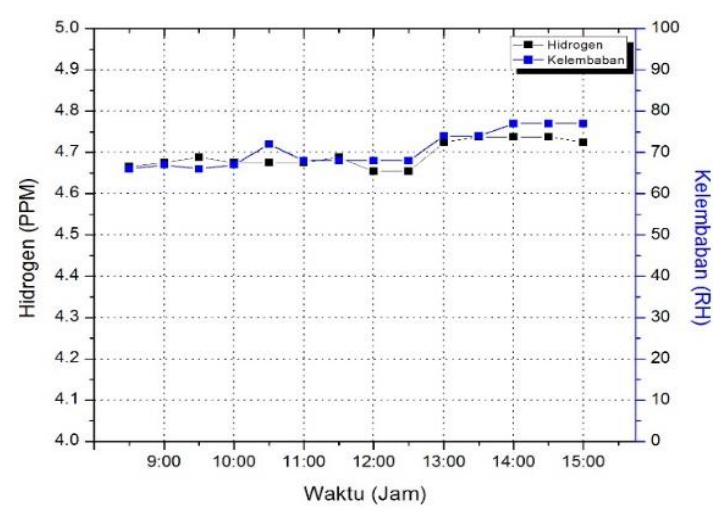

Gambar 8. Pengaruh kelembaban terhadap produksi gas hydrogen

Pada kondisi tekanan dari rentang 100,5100,6 produksi gas hydrogen tidak terlihat begitu signifikan, produksi gas hidrogen berada pada rentang 4,65-4,68 ppm, kondisi ini terjadi mulai pukul 8:30 hingga 12:00. Pada pukul 13:00 terjadi kenaikan produksi hingga 4,72 ppm namun puncak produksi gas hidrogen terjadi pada pukul 13:30-14:30 dengan produksi mencapai 4,73 ppm dengan kondisi tekanan pada rentang $100,3-100,4 \mathrm{kPa}$.

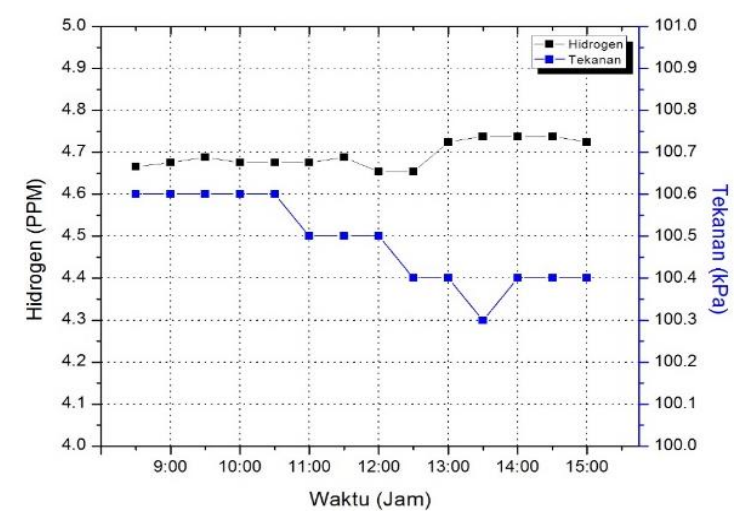

Gambar 9. Pengaruh tekanan terhadap produksi gas hidrogen

\subsection{Pengujian sensor gas MG811}

Gambar 10 menunjukkan hubungan pengaruh perubahan suhu terhadap produksi gas karbondioksida dalam biodigester, pada saat suhu turun dari $34^{\circ} \mathrm{C}$ menjadi $33^{\circ} \mathrm{C}$ produksi gas karbondioksida menunjukkan pada 16,89 ppm. 


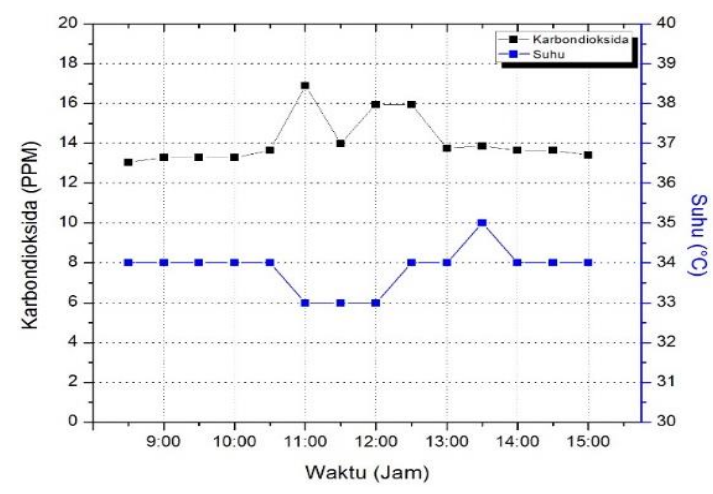

Gambar 10. Pengaruh suhu terhadap produksi gas karbondioksida

Pada kondisi suhu naik dari $33^{\circ} \mathrm{C}$ menjadi $34^{\circ} \mathrm{C}$ Produksi gas karbondioksida menjadi 15,96 ppm. Produksi gas karbondioksida menjadi stabil pada kondisi suhu $34^{\circ} \mathrm{C}$ dengan produksi sebesar 13,64 ppm hingga pukul 15:00.

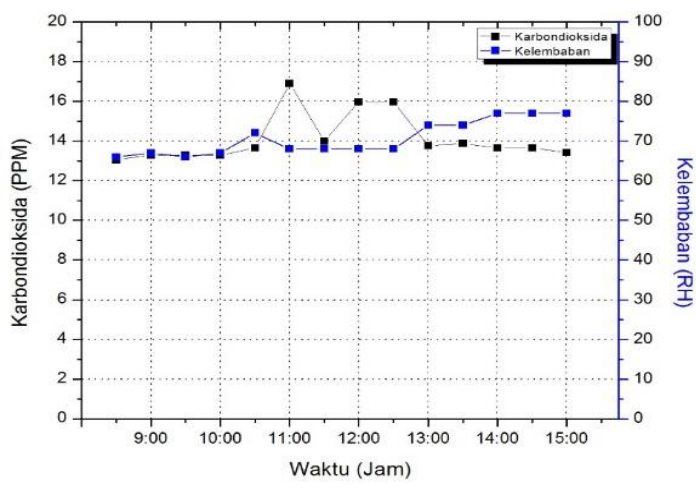

Gambar 11. Pengaruh kelembaban terhadap produksi gas karbondioksida

Gambar 11. merupakan grafik yang menunjukkan hubungan antara produksi gas karbondioksida dengan perubahan kelembaban dalam biodigester. Jika dilihat dari perubahan grafik, terdapat beberapa pengaruh kenaikan kelembaban, puncak produksi gas karbondioksida terjadi pada pukul 11:00 yaitu mencapai 16,89 ppm dengan kondisi kelembaban sebesar 68\%. Pada pukul 11:30 produksi gas mengalami penyusutan hingga mencapai 13,99 ppm, namun kembali naik hingga $15,96 \mathrm{ppm}$ dan terjadi penurunan produksi menjadi 13.76 pada saat kelembaban naik dari $68 \%$ menjadi $74 \%$. Hal ini menunjukkan bahwa perubahan kelembaban berbanding terbalik terhadap produksi gas karbondioksida

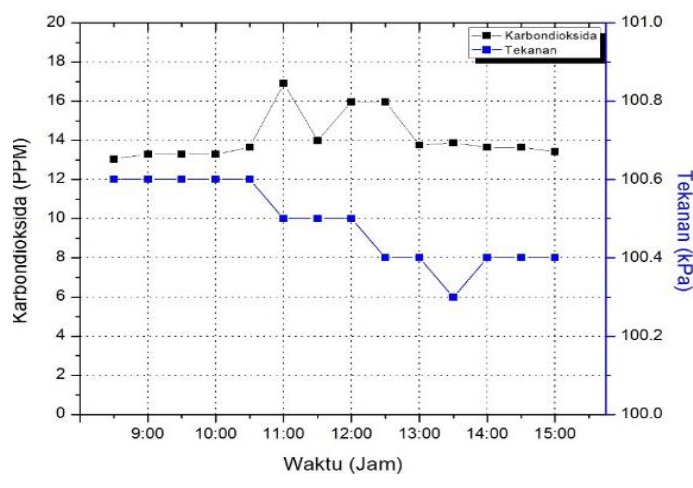

Gambar 12. Grafik pengaruh tekanan terhadap produksi gas karbondioksida

Pada Gambar 12 menunjukkan hubungan pengaruh tekanan terhadap produksi gas karbondioksida, hasil pengujian menunjukkan bahwa produksi gas karbondioksida pada pukul 11:00 merupakan titik tertinggi produksi gas karbondioksida, yaitu dengan jumlah produksi sebesar 16,89 ppm pada kondisi tekanan 100,5 $\mathrm{kPa}$. Pada pukul 13:00-15:00 produksi karbondioksida berada pada kondisi yang stabil sebesar 13,4-13,7 ppm dengan kondisi tekanan berada pada rentang $100,3 \mathrm{kPa}-100,4 \mathrm{kPa}$.

\section{KESIMPULAN}

Dari hasil penelitian yang telah dilakukan dapat disimpulkan sebagai berikut.

1. Sistem instrumen yang digunakan untuk proses monitoring konsentrasi gas metana, hidrogen, dan karbondioksida ini dapat melakukan proses akuisisi data dengan baik, serta data yang terbaca pada mikrokontroller dapat dikirimkan ke PC.

2. Parameter suhu, kelembaban dan tekanan dapat mempengaruhi produksi biogas, pada pengujian terhadap gas metana, didapatkan titik tertinggi produksi gas metana terjadi pada pukul 10:00 menghasilkan 95672 ppm dengan kondisi suhu $34^{\circ} \mathrm{C}$, kelembaban: $67 \% \mathrm{RH}$, dan tekanan 100,6 kPa. Untuk gas hidrogen didapat titik tertinggi produksi terjadi pada pukul 14:00 menghasilkan 4,738 ppm dengan kondisi suhu $34^{\circ} \mathrm{C}$, kelembaban $74 \%$ RH, dan tekanan 100,4 kPa. Pada gas karbondioksida titik tertinggi produksi gas terjadi pada pukul 11:00 menghasilkan 16,89 ppm dengan kondisi suhu $33^{\circ} \mathrm{C}$, kelembaban $68 \% \mathrm{RH}$, dan tekanan $100,5 \mathrm{kPa}$. 
3. Setelah dilakukan perancangan dan pengujian, sistem monitoring ini dapat diimplementasikan pada sebuah digester dengan baik.

\section{DAFTAR PUSTAKA}

[1] Faiz, Suyanto, Uji Kinerja Taguchi Gas Sensor (TGS) Untuk Monitoring Gas Methane Pada Portable Biodigester, Intitut Teknologi Surabaya, Surabaya, 2014.

[2] L. Katriani, Potensi Pengaplikasian Sistem Instrumentasi Sebagai Pendeteksi Gas Metana ( $\mathrm{CH} 4)$ yang Terkandung dalam Biogas, Universitas Negeri Yogyakarta, Yogyakarta, 2014.

[3] A. Marwan, Analisis Produktifitas Gas Hidrogen Dan Gas Oksigen Pada Elektrolisis Larutan Koh, Jurnal Neutrino Vol. 2 No. 2, 2010.

[4] D. Arintya, Sumardi, I. Setiawan, Monitoring Kandungan Karbondioksida (Co2) Dalam Sebuah Model Ruangan Berbasis Mikrokontroler Atmega8535, Universitas Diponegoro, Semarang, 2011.

[5] Indra, Lazuardy, Rancang Bangun Alat Penghasil Biogas Model Terapung, Universitas Sumatera Utara, Sumatera Utara, 2008.

[6] C. Bambang, Armansyah, N. Hayati A. Jaffar, Cheng Yee, S. Kasolang, Wireless e-Nose Sensor Node : State of the Art, International Symposium on Robotics and Intelligent Sensors 2012 (IRIS 2012), ScienceDirect, 2012.

[7] S. Abraham, X Li, A Cost Effective Wireless Sensor Network System for Indoor Air Quality Monitoring Applications, University of North Texas, Texas, 2014.

[8] R. Andri, Sistem Monitoring dan Pengendalian Suhu dan Kelembaban Ruang pada Rumah Walet Berbasis Android, Web, dan SMS, Institut Teknologi Sepuluh Nopember (ITS), Surabaya, 2013.

\section{Biodata Penulis}

Rocky Alfanz, Lahir pada 28 Maret 1981. Meraih gelar Master of Science (M. Sc) di National Taiwan University 2009 Master Degree
Electrical Engineering (Institute biomedical Engineering) dan meraih gelar S.T di Universitas Jayabaya Jakarta. Sekarang Aktif sebagai pengajar di lingkungan Jurusan Teknik Elektro Universitas Sultan Ageng Tirtayasa. Aktif melakukan penelitian dibidang Elektronika Biomedical engineering, Ilmu Material, Photovoltaic Sistem, serta aktif dalam Ikatan Polimer Indonesia (HPI) dalam bidang Ilmu Bahan untuk power sistem bidang material Photovoltaic. Salahsatu karya ilmiah yang pernah diterbitkan dalam skala internasional adalah: "Identification Disturbance on Transformer Using Wavelet Transformation" pada International Journal of Engineering Research and Technology (IJERT) 2015.

Agus Nurhadi, Lahir di Serang pada tanggal 29 Juli 1993. Mahasiswa Sarjana Teknik Elektro di Universitas Sultan Ageng Tirtayasa - Banten. Pernah mengikuti Kontes Robot Indonesia tahun 2013, 2014 divisi KRPAI Berkaki sebagai ketua tim dan programmer. Pernah menjabat sebagai asisten laboratorium Pengolahan Sinyal Digital di Laboratorium Teknik Elektro UNTIRTA.

Joddy Arya Laksmono, Mahasiswa program doktoral di Universitas Indonesia, aktif sebagai peneliti di lingkungan Pusat Penelitian Kimia LIPI Serpong dengan pangkat golongan III/c. Fokus pada kegiatan penelitian teknik reaksi kimia, kinetika dan termodinamika reaksi, transfer massa dan panas serta separasi dan purifikasi. Dan profil lebih lanjut bias diakses pada halaman: http://sivitas.lipi.go.id/jodd001/ 